\title{
Keynote Address \\ More Instruments and Broader Goals: Moving Toward the Post-Washington Consensus
}

\author{
Joseph E. Stiglitz
}

Today I would I like to discuss improvements in our understanding of economic development. In particular, I would like to use this opportunity to discuss the emergence of what is sometimes called the "Post-Washington Consensus."

My remarks elaborate on two themes. The first is that we have come to a better understanding of what makes markets work well. The Washington Consensus held that good economic performance required liberalized trade, macroeconomic stability, and getting prices right. ${ }^{1}$ Once the government handled these issues essentially, once the government "got out of the way" - private markets would produce efficient allocations and growth. To be sure, all of these are important if markets are to work. It is very difficult for investors to make good decisions when inflation is running at 100 percent. But the policies advanced by the Washington Consensus are hardly complete - and they are sometimes misguided. Making markets work requires more than just low inflation. It requires sound financial regulation, competition police and policies to facilitate the transfer of technology, and transparency, to name some fundamental issues that the consensus neglects.

At the same time that we have improved our understanding of the instruments to promote well-functioning markets, we have broadened the objectives of development to include other goals like sustainable development, egalitarian development, and democratic development. An important part of development today is seeking complementary strategies that advance these goals simultaneously. In our search for these policies, however, we should not ignore the inevitable tradeoffs. This is the second theme of my remarks.

\section{Some Lessons of the East Asian Financial Crisis}

Before discussing my two themes, I would like to address at the outset one issue that is on many people's minds: the implications of the East Asian crisis for our thinking about development. The observation of the successful, some even say miraculous, East Asian development was one of the motivations for moving

1 For the initial exposition of the Washington Consensus see Williamson (1990).

Joseph E. Stiglitz is chief economist and senior vice president, Development Economics, at the World Bank.

Villa Borsig Workshop Series 1998

(C) 1999 German Foundation for International Development (DSE) 
beyond the Washington Consensus. After all, here was a regional cluster of countries that had not closely followed the Washington Consensus prescriptions but that had somehow managed the most successful development in history. To be sure, many of their policies - like low inflation and fiscal prudence were perfectly in line with the Washington Consensus. But many, especially in the financial sector, were not. This observation was the basis for the World Bank's study, The East Asian Miracle (World Bank 1993) as well as a stimulus for the recent rethinking of the role of the state in economic development.

With the emergence of the financial crisis, the East Asian economies have been transformed in the minds of many observers from development success story to misguided followers of flawed economic policies that have led them to the mess in which they find themselves today. Some ideologues have taken advantage of the current problems besetting East Asia to suggest that the system of active state intervention is the root of the problem. They refer to the government-directed loans and the cozy relations with the large chaebol in the Republic of Korea. They conveniently forget the not inconsiderable successes of the past three decades - successes to which government, despite its occasional mistakes, has certainly contributed. These achievements are real. They are not a house of cards. No temporary financial turmoil can detract from these achievements, which include not only large increases in per capita GDP, but also extended life spans, widespread education, and dramatically reduced poverty.

Even when the governments directly undertook actions, they had notable achievements. They created the most efficient steel plants, contrary to the claims of privatization ideologues who suggested that such successes are at best a fluke, and at worst impossible. I agree that government should focus on what it alone can do, and it should leave the production of commodities like steel to the private sector. But the heart of the current problem in most cases is not that government has done too much, but that it has done too little. In Thailand it was not that government directed the investments into real estate; it was that government regulators failed to halt it.

Similarly, in Korea there was a big problem of lending to companies with excessively high leverage, and corporate governance issues that include widespread cross-subsidization. The fault is not that the government misdirected credit (and, indeed, the problems faced by many U.S. and European banks suggest that they also may have seriously misdirected credit). Rather, the problem was the government's lack of action - the fact that the government underestimated the importance of financial regulation and corporate governance.

The East Asian crisis is not a refutation of the East Asian miracle. The more dogmatic versions of the Washington Consensus do not provide the right framework for understanding both the success and the current troubles of the East Asian economies. Responses to the East Asian crisis grounded in this view of the world are likely to be badly flawed and even counterproductive. 


\section{Making Markets Work Better}

The Washington Consensus was catalyzed by the experience of Latin American countries in the 1980s. At the time the economies in the region were clearly not functioning at all. GNP contracted for three straight years in the early 1980s. The inability of markets to function was clearly related to dysfunctional public policies. Budget deficits were very high - many were as high as 5 to 10 percent of GDPand the spending underlying them was not being used for productive purposes but was being diverted to subsidize the huge and inefficient state sector. With strong curbs on imports and relatively little emphasis on exports, firms had insufficient incentives to increase efficiency or to reach and maintain international quality standards. At first deficits were financed by borrowing - including very heavy borrowing from abroad. Rising real interest rates in the United States brought an end to continued borrowing and increased the burden of interest payments, forcing many countries to resort to seigniorage to finance the gap between high levels of public spending and the shrinking tax base. The result was very high and extremely variable inflation. In this environment money became a much costlier means of exchange, economic behavior was diverted to protecting value rather than making productive investments, and the relative price variability induced by the high inflation undermined one of the primary functions of the price system, conveying information.

It was in the midst of these serious problems that the so-called Washington Consensus emerged among U.S. economic officials, the International Monetary Fund (IMF), and the World Bank. I think that now is a good time to reexamine this consensus. Many countries, like Argentina and Brazil, have pursued successful stabilizations, and the challenges they face are in designing the next generation of reforms. Still other countries have always had relatively good policies or face problems quite different from those of Latin America. In East Asia, for instance, many governments have been running government surpluses and prior to the devaluations, inflation was low and falling (figures 1 and 2). The origins of the current financial crises are elsewhere, and the solutions will not be found in the Washington Consensus either.

I will argue that the focus on inflation - the central macroeconomic malady of the Latin American countries and the backdrop for the Washington Consensus has led to macroeconomic policies that may not be the most conducive for longterm economic growth and has pulled attention away from other major sources of macroeconomic instability, namely weak financial sectors. The focus on freeing up markets as it applied to financial market liberalization may actually have had a perverse effect, contributing to macroeconomic instability through a weakening of the financial sector. More broadly, the focus on trade liberalization, deregulation, and privatization ignored other important ingredients required to make an effective market economy, most notably competition; in the end competition may be at least as important as these other ingredients in determining long-term economic success. 
I will also argue that there are other ingredients essential to economic growth that were left out or underemphasized by the Washington Consensus. One of these, education, has been widely recognized within the development community, but the others, such as improvement of technology, may not have received the attention they deserve.

The success of the Washington Consensus as an intellectual doctrine rests on its simplicity. Although many of its proponents are very sophisticated and subtle in their thinking, its policy recommendations could be administered by economists using little more than simple accounting frameworks. They could look at a few economic indicators - at inflation, money supply growth, interest rates, budget and trade deficits - and form a picture of the economy and then craft a set of recommendations. Indeed, there have been cases in which economists would fly into a country, look at and attempt to verify these data, and make macroeconomic recommendations for policy reforms all in the space of a couple of weeks. ${ }^{2}$

There are important advantages to the Washington Consensus approach to policy advice. It focuses on issues of first-order importance, it sets up an easily reproducible framework, and it is frank in its limitation to establishing the prerequisites for development. But for these reasons the Washington Consensus does not offer the most important answers for every question in development. Deluding ourselves into thinking that it does can lead to misguided policies.

In contrast, the ideas that I discuss here are not so simple; there are no easy to read thermometers of the economy's health. And worse still, there may be tradeoffs in which the economist's task is to describe alternative consequences of different policies, but in which the political process may actually have an important say in the choice of economic direction. Economic policy may not be just a matter for technical experts! These conflicts become all the more important when it comes to the broader development objectives, as I discuss later in this paper.

\section{Macroeconomic Stability}

Controlling Inflation. Probably the most important element of the stabilization packages promoted by the IMF and others has been controlling inflation. The argument for aggressive, preemptive strikes against inflation is based on three premises. The most fundamental premise is that inflation is costly. This provides the motivation for trying to avert or lower inflation. The second premise is that once inflation starts to rise it has a tendency to accelerate out of control. This belief provides a strong motivation for erring on the side of caution in fighting inflation.

\footnotetext{
2 These issues came up in the management of the U.S. economy. While much research showed that the United States was able to operate at lower levels of unemployment without an acceleration of inflation, the bright line approach recommended tightening of monetary policy. Had this advice been followed, the remarkable expansion of the U.S. economy, its low unemployment rate - which brought marginalized groups into the labor market, reduced poverty, and contributed substantially to the reduction of welfare rolls - would all have been thwarted (see chapter 2 of the Economic Report of the President 1997 for some of this analysis).
} 
Finally, the third premise is that increases in inflation are costly to reverse. The implication of this premise is that even if you care much more about unemployment than inflation, you would still keep inflation from increasing today in order to avoid having to induce large recessions to bring inflation down later on. All three of these premises are hypotheses that can be tested empirically.

I have discussed this evidence in more detail elsewhere (Stiglitz 1997). Here I would like to summarize it briefly. The evidence has shown only that high inflation is costly. Bruno and Easterly (1996) found that when countries cross the threshold of 40 percent annual inflation they fall into a high inflationary growth trap. But below that level there is no evidence that inflation is costly. ${ }^{3}$ Barro (1997) and Fischer (1993) also confirm that high inflation is, on average, deleterious for growth, but again they failed to find any evidence for costs of low levels of inflation. Fischer also found the same results for the variability of inflation. ${ }^{4}$ Recent research by Akerlof, Dickens, and Perry (1996) suggests that low levels of inflation may even improve economic performance.

The evidence on the accelerationist hypothesis (also known as letting the genie out of the bottle or the slippery slope) is unambiguous: there is no evidence that an increase in the inflation rate is related to past increases in inflation. Finally, in reference to the third proposition, some recent work has suggested that the Phillips curve may be concave and thus that the costs of reducing inflation may be smaller than the benefits reaped when inflation was rising.

In my view, the conclusion of this research into the consequences of inflation is that controlling high and medium rates of inflation should be a fundamental policy priority but that pushing low inflation even lower is not likely to significantly improve the functioning of markets.

In 1995 more than half of the countries in the developing world had inflation rates below 15 percent (figure 3). For these 71 countries controlling inflation should not be a major priority. Controlling inflation is probably an important component of stabilization and reform in the 22 countries with inflation rates above 40 percent, almost all of them in Africa, Eastern Europe, and the former Soviet Union. Interestingly, the Washington Consensus emphasis on inflation was, if anything, less relevant in the 1980s, when even fewer countries had very high inflation rates.

3 The null hypothesis in this, as in most other studies of inflation, is that inflation is costless. The failure to reject this null at low levels of inflation does not prove that inflation is costless, only that we have no evidence that it is costly.

4 Because the level and variability of inflation are so correlated, Fischer reported great difficulty in disentangling their separate effects at any level or vance of inflation. This point holds true more generally: any study of the consequences of inflation probably also picks up costs associated with the variability of inflation.

The strength of the nonlinearity in the relationship between inflation and social welfare is clear from the outcome of research conducted by the U.S. Federal Reserve Bank. Despite the efforts of their minions of first-rate economists - some of them working full time on the costs of inflation - the Fed has still failed to find definitive evidence of costs of inflation in the United States. Should they eventually succeed in finding such results, they will only have proven that data mining does work, not that inflation does not. 
Reducing THE BUdget Deficit AND CURRENT ACCOUnt DEFICIT. A second component of macroeconomic stability has been reducing the size of government, the budget deficit, and the current account deficit. I return to the issue of the optimal size of government later; here I focus on the twin deficits. Like inflation, much evidence shows that large budget deficits are deleterious to economic performance (Fischer 1993; Easterly, Rodriguez, and Schmidt-Hebbel 1994). ${ }^{5}$ The three methods of financing deficits all have drawbacks: internal finance raises domestic interest rates, external finance can be unsustainable, and money creation causes inflation.

But there is no simple optimum level of the budget deficit. The optimum deficitor the range of sustainable deficits - depends on circumstances, including the cyclical state of the economy, prospects for future growth, the uses of government spending, the depth of financial markets, and the levels of national savings and national investment. The United States, for example, is trying to balance its budget. I think that the United States should probably aim for budget surpluses, considering its low private savings rate and the aging of the baby boom generation. In contrast, the case for maintaining budget surpluses in the East Asian countries, with their high private savings and transitory growth slowdown, is less compelling.

Ethiopia's experience emphasizes another determinant of optimal deficits, the source of financing. For the last several years Ethiopia has run a deficit of about 8 percent of GDP. Some policy advisers would like Ethiopia to lower its deficit. Others have argued that the deficit is financed by a steady and predictable inflow of highly concessional foreign assistance, aid driven not by the necessity of filling a budget gap but by the availability of high returns to investment. In these circumstances - and given the high returns to government investment in such crucial areas as primary education and physical infrastructure (especially roads and energy) - it may make sense for the government to treat foreign aid as a legitimate source of revenue, just like taxes, and to balance the budget inclusive of foreign aid.

The optimal level of the current account deficit is also indeterminate in general. Current account deficits, as we all know, occur when a country invests more than it saves. They are neither inherently good nor inherently bad, but depend on the circumstances, especially on the use of the investment. In many countries the rate of return on investment far exceeds the cost of international capital. In these circumstances current account deficits are sustainable. ${ }^{6}$

The form of the financing also matters. The advantage of foreign direct investment is not just the capital and knowledge that it supplies, but also the fact that it tends to be very stable. In contrast, Thailand's 8 percent current account deficit last year was not only large but came in the form of short-term, dollar-denomi-

5 The theoretical literature on Ricardian equivalence (Barro 1974) criticizes the view that the deficit by itself has significant economic effects. Although this literature has been criticized on both theoretical and empirical grounds, the Washington Consensus was not based on models that explicitly addressed the issue of Ricardian equivalence.

6 The current account deficit is an endogenous variable. Assessin whether it is too "high" depends on the explanation for its size, for example, misguided foreign exchange policies. 
nated debt that was used to finance local currency-denominated investment, often in excessive and unproductive uses like real estate. More generally, short-term debt and portfolio flows can bring the costs of high volatility without the benefits of knowledge spillovers. ${ }^{7}$

STABILIZING OUTPUT AND PROMOTING LONG-RUN GROWTH. Ironically, macroeconomic stability - as seen by the Washington Consensus - typically downplays the most fundamental element of stability: stabilizing output or unemployment. Minimizing or avoiding major economic contractions should be one of the most important goals of policy. In the short run, large-scale involuntary unemployment is clearly inefficient. In purely economic terms it represents idle resources that could be used more productively. Also some research to which I have contributed has emphasized that business cycles themselves can have important consequences for long-run growth. ${ }^{8}$ The research found that the difficulty of borrowing to finance research and development means that firms will need to drastically reduce their expenditures on research and development when their cash flow slows in a downturn. The result is slower total factor productivity growth in the future. The research also found evidence that this effect is important in the United States: whether it matters in countries in which research and development plays less of a role requires further study. But more generally, variability of output almost certainly contributes to uncertainty, and thus discourages investment.

Variability of output is especially pronounced in developing countries. ${ }^{9}$ The median high-income country has a standard deviation of annual growth rates of 2.8, while the median developing country has a standard deviation of 5 percent or higher - implying huge deviations in the growth rate (figure 4). As one would expect, growth is especially volatile in Europe and Central Asia, the Middle East and North Africa, and Sub-Saharan Africa.

How can we promote macroeconomic stability in the sense of stabilizing output or employment? The traditional answer is good macroeconomic policy, including countercyclical monetary policy and a fiscal policy that allows automatic stabilizers to operate. These policies are certainly necessary, but a growing literature, both theoretical and empirical, emphasizes the important microeconomic underpinnings of macroeconomic stability, such as financial markets, and explains economic downturns through such mechanisms as credit rationing and banking and firm failures. ${ }^{10}$

7 Traditional government macroeconomic policies do not deal directly with these issues. If the maturity structure of foreign borrowing leads to significant risks, other capital restraints may be necessary.

8 See Stiglitz (1994) for a broad overview of my research with Bruce Greenwald and Andrew Weiss on this issue.

9 A very creative exploration of this idea is contained in Pritchett (1997).

10 This sometimes is described as debt deflation because fixed interest payments reduce firms cash flows in economic downturns, decreasing their investment and further weakening the economy; see Greenwald and Stiglitz $(1988,1993 a, b)$. 
In the $19^{\text {th }}$ century most of the major economic downturns in industrial countries resulted from financial panics that were sometimes preceded by but invariably led to precipitous declines in asset prices and to widespread banking failures. In some countries improvements in regulations and supervision, the introduction of deposit insurance, and the shaping of incentives for financial institutions have all reduced the incidence and severity of financial panics. Even so, financial crises continue, and there is some evidence that they have gotten more frequent and more severe in recent years (Caprio and Klingebiel 1997). The losses from the notorious savings and loan debacle in the United States were, even after adjusting for inflation, several times larger than the losses experienced in the Great Depression. Yet this debacle, when measured relative to GDP, would not make the top 25 banking crises since the early 1980s. Table 1 shows the fiscal cost of banking crises relative to GDP in selected countries.

Banking crises have severe macroeconomic consequences. During 1975-94 growth edged up slightly in countries that did not experience banking crises (figure 5). Countries with banking crises saw growth slow by 1.3 percentage points in the five years following a crisis. Clearly, building robust financial systems is a crucial part of promoting macroeconomic stability.

\section{Financial Reform}

The importance of building robust financial systems goes beyond simply averting economic crisis. I have sometimes likened the financial system to the brain of the economy. It plays an important role in collecting and aggregating savings from agents who have excess resources today. These resources are allocated to others - like entrepreneurs and home builders - who can use them productively. Well-functioning financial systems do a very good job of selecting the most productive recipients for these resources. In contrast, poorly functioning financial systems will often allocate capital to low-productivity investments. Selecting projects is only the first stage. The financial system needs to continue to monitor the use of funds, ensuring that they continue to be used productively. In the process financial systems serve a number of other functions, including reducing risk, increasing liquidity, and conveying information. All of these functions are essential to both the growth of capital and the increase in total factor productivity.

Left to themselves, financial systems will not do a very good job of fulfilling these functions. The most important lesson of the theory and observation of financial markets is the pervasiveness of market failure. Incomplete information, incomplete markets, and incomplete contracts are all particularly severe in the financial sector, resulting in an equilibrium that is not even constrained-Pareto efficient (Greenwald and Stiglitz 1986). A sound legal framework combined with regulation and oversight is necessary to mitigate these information problems and foster the conditions for efficient financial markets.

In successful financial markets regulations serve four purposes: maintaining safety and soundness (prudential regulation), promoting competition, protecting 
consumers, and ensuring that underserved groups have some access to capital. In many cases, the pursuit of social objectives - such as ensuring a supply of funds to minorities and poor communities (as under the U.S. Community Reinvestment Act), ensuring a supply of funds for mortgages (the essential mission of the U.S. government-created Federal National Mortgage Association), or ensuring a supply of funds for small businesses (the central objective of the U.S. Small Business Administration - can, if done well, reinforce economic objectives. Similarly, protecting consumers is not only good social policy, but is also essential for maintaining confidence in a level playing field in economic markets, without which those markets will remain thin and ineffective.

There are times, however, when policymakers might face tradeoffs among conflicting objectives. For instance, the East Asian countries adopted financial restraints. These restraints increased the franchise values of banks, discouraging them from taking unwarranted risks that otherwise might have destabilized the banking sector. Although there were undoubtedly some economic costs associated with these restraints, the gains from greater stability almost surely outweighed these losses.

Previous efforts by the World Bank and others have tried to build better banking systems. In practice, however, the changes, including institutional development, changes in credit culture, and moral hazard, have all proved harder to make progress on than such short-term solutions as recapitalizing the banking system. In the worst cases, however, these temporary fixes may have undermined pressures for further reform. And since the fundamental problems were not addressed, we would sometimes find ourselves returning to the same countries over and over again.

The Washington Consensus developed in a context of highly regulated financial systems, with regulations designed more to limit competition than to promote any of the four legitimate objectives of regulation. But all too often the dogma of liberalization became an end in itself, not a means to a better financial system. I do not have time to delve into all of the many facets of liberalization, which include freeing up deposit and lending rates, opening up to foreign banks, removing restrictions from capital account transactions, and removing restrictions on bank lending. But I do want to make a few general points.

First, the key issue should not be liberalization or deregulation, but the construction of a regulatory framework that ensures an effective financial system. This will require, in many countries, changing the regulatory framework and eliminating regulations that serve only to restrict competition. But the changes need to be accompanied by increased regulations to ensure competition and prudential behavior (and to ensure that banks have appropriate incentives).

Second, even once the design of the desired financial system is in place, due care will have to be exercised in the transition. The attempt to deregulate almost overnight, sometimes known as the "big bang," ignores the very sensitive issues of sequencing. Thailand, for instance, used to have restrictions on bank lending to real estate. In the process of liberalization it got rid of these restrictions without 
establishing a more sophisticated risk-based regulatory regime. Combined with several other factors, the result was the large-scale misallocation of capital to fuel a real estate bubble, an important factor in the financial crisis.

It is important to recognize how difficult it is to establish a vibrant financial sector. Even economies with sophisticated institutions, like the United States and Sweden, have faced serious problems with their financial sectors. The challenges developing countries face are all the greater, and yet the institutional base from which they start is all the weaker.

Third, in all countries a primary objective of regulation should be to ensure that participants have the right incentives: government cannot and should not be involved in monitoring every transaction.

In the banking system, liberalization will not work unless regulations create incentives for bank owners, markets, and supervisors to use their information efficiently and act prudentially. It is equally important to address incentive issues in securities markets. It must be more profitable for managers to create economic value than to deprive minority shareholders of their assets: rent seeking can be every bit as much a problem in the private as in the public sector. The Czech Republic has shown that without the appropriate legal framework, securities markets can fail to perform their vital functions - much to the detriment to the country's long-term economic growth. Laws are required to protect the interests of shareholders, especially minority shareholders.

The focus on the microeconomic, particularly financial, underpinnings of the macroeconomy also has implications for responses to currency turmoil. In particular, when currency turmoil is the consequence of a failing financial sector, the conventional policy response of increasing interest rates may be counterproductive. ${ }^{11}$ The maturity and interest rate composition of bank and corporate assets and liabilities are frequently very different, in part because of the strong incentives for banks to use short-term debt to monitor and influence borrower firms and for depositors to use short-term deposits to monitor and influence banks (Rey and Stiglitz 1993). As a result, interest rate increases can lead to substantial reductions in bank net worth-further exacerbating the banking crisis. Empirical studies have confirmed that interest rate rises tend to increase the probability of banking crises and that currency devaluations have no significant effect (Demirgüç-Kunt and Detragiache 1997). ${ }^{12}$

11 Supporters of these policies, while recognizing the problems, argue that a temporary increase in interest rates is required to restore confidence and that so long as the interest rare measures are very short term, little damage will be done. Whether increases in interest rates will, or should, restore confidence has been much debated. The evidence in recent experience is not fully supportive. In any case, Thailand and Indonesia have been pursuing high-interest rate policies for months.

12 Most analyses of the U.S. saving and loan crisis place the ultimate blame on the unexpectedly large increases in interest rates in the early 1980s under then-Fed Chairman Paul Volcker. The value of assets plunged, leaving many with a low or negative net worth. Attempts to patch up the problem (part of regulatory forbearance) failed, exacerbating the magnitude of the problem, until by the late 1980 s, the problem could no longer be ignored. 
There is another reason that government should perhaps be more sensitive to interest rate changes than to exchange rate changes: while there is an economic logic between maturity mismatches, there is no corresponding justification for exchange rate mismatches. There is a real cost associated with forcing firms to reduce maturity mismatches. Exchange rate mismatches, by contrast, simply represent speculative behavior. In practice, policy cannot rely on these general nostrums, but needs to look carefully at the situation within the country in crisis. It is possible that currency mismatches are far larger than maturity mismatches, and while future actions might be directed at correcting such speculation with its systemic effects, current policy must deal with the realities of today.

\section{Competition}

I want to return to our broader theme: making markets work better. So far I have argued that macroeconomic policy needs to encompass more than a singleminded focus on inflation and budget deficits. The set of policies underlying the Washington Consensus is neither necessary nor sufficient for macroeconomic stability or long-term development. Achieving these goals requires sound financial markets, but the agenda for creating sound financial markets should not confuse means with ends. Financial liberalization is not the issue. Redesigning the regulatory system is - or should be.

Central to the success of a market economy is competition. Here, too, there has been some confusion between means and ends. Policies that should have been viewed as means to achieve a more competitive marketplace were instead seen as ends in themselves and as a result, they sometimes failed to attain their objectives.

The fundamental theorems of welfare economics, the results that establish the efficiency of a market economy, have two basic assumptions: private property and competitive markets. Many countries, especially developing and transition economies, are lacking in both. Until recently, however, emphasis has been placed almost exclusively on creating private property and liberalizing trade - with liberalizing trade being confused with establishing competitive markets. These are important objectives, but we are unlikely to realize their full benefits without creating a competitive economy.

FrEe TrADE. Trade liberalization, leading eventually to free trade, was a key part of the Washington Consensus. The emphasis on trade liberalization was natural. Latin American economies had stagnated behind protectionist barriers. ${ }^{13}$ Import substitution proved a highly ineffective strategy for development. In many countries industries were producing products with negative value added and innova-

13 Still, advocates of import substitution point out that during certain periods, countries that pursued such policies did achieve strong economic growth, notably Brazil and Taiwan (China) in the 1900s. 
tion was stifled. ${ }^{14}$ Trade liberalization may create competition, but it does not do so automatically. If trade liberalization occurs in an economy with a monopoly importer, rents would simply be transferred from the government to the monopolist, with little decrease in prices. Trade liberalization is neither necessary nor sufficient for creating a competitive and innovative economy.

As or more important than creating competition in the previously sheltered import-competing sector of the economy is promoting competition on the export side. The success of the East Asian economies is a particularly powerful example. By allowing each country to take advantage of its comparative advantage, trade increases wages and expands consumption opportunities. For the last 15 years trade has been doing just that - with world trade growing at a 5 percent annual rate, nearly twice the rate of world GDP growth.

Interestingly, we do not fully understand the process by which trade liberalization leads to enhanced productivity. The standard Hecksher-Ohlin theory predicts that countries will shift intersectorally, moving along their production possibility frontier. They will produce more of what they are better at and trade for what they are worse at. In reality the main gains from trade seem to come intertemporally, from an outward shift in the production possibility frontier from increased efficiency, with little sectoral shift. Understanding the causes of this improvement in efficiency requires an understanding of the links between trade, competition, and liberalization. This is an area that needs to be pursued further. ${ }^{15}$

Privatization. Many countries have (or had) state monopolies in certain industries that stifle competition. But the emphasis on privatization over the past decade has come not so much from the concern about competition, as from a focus on incentives. As mentioned previosuly, essential to a market economy are free, competitive markets and private property. Many countries - especially those in the former socialist bloc - lacked both.

The Washington Consensus focused more on privatization than on competition. In a sense it was natural for them to do so. Not only were the state enterprises inefficient, but their losses contributed to the government budget deficit, which contributed to macroeconomic instability. Privatization would kill two birds with one stone: it would simultaneously improve economic efficiency and reduce fiscal

14 But the usual argument was somewhat confused: it was lack of competition that stifled innovation, not protectionism itself. Governments could have created competition among domestic firms, which would have provided incentives to import new technology. It was the failure to create competition internally more than the protection from abroad that was the cause of the stagnation. Competition from abroad would have, of course, provided an important source of competition, but it is possible that in the one-sided race, domestic firms would have dropped out of the competition rather than enter the fray. Consumers might have benefited, but the effects on growth may have been more ambiguous.

15 Elsewhere, I have explained how trade liberalization may both enhance incentives and opportunities for innovative activity (including the transfer of technology). The adverse effects associated with protectionism may come more from its impact on competition and its inducement to rent seeking behavior. These forces are so strong that even when there might be seemingly strong arguments for trade interventions, based, for instance, on strategic trade theory, most economists view intervention in trade policy with considerable skepticism. 
deficits. The idea was that, once property rights were created, the profit-maximizing behavior of owners would then eliminate waste and inefficiency. At the same time the sale of the enterprises would raise much needed revenue for the state.

In the transition economies rapid privatization represented a reasonable gamble. Although most people would have preferred a more orderly restructuring and establishment of an effective legal structure (covering contracts, bankruptcy corporate governance and competition), no one knew how long the reform window would stay open. At the time, privatizing quickly and comprehensively and fixing the problems later - seemed a reasonable gamble. In retrospect, it seems clear that the advocates of privatization overestimated the benefits of privatization and underestimated the costs, particularly the political costs of the process itself and the impediments to further reform. Taking that same gamble today, with the benefit of seven more years of experience, would be much less justified.

Even at the time many of us warned against hastily privatizing without creating the needed institutional infrastructure, including competitive markets and regulatory bodies. The conditions under which privatization can achieve the public objectives of efficiency and equity are very limited and very similar to the conditions under which competitive markets attain Pareto-efficient outcomes (see the fundamental theorem of privatization in Sappington and Stiglitz 1987). If, for instance, competition is lacking, then creating a private, unregulated monopoly will likely result in even higher prices for consumers. And there is some evidence that, insulated from competition, private monopolies may suffer from several forms of inefficiency and may not be highly innovative.

Indeed, large-scale public and private enterprises share many similarities and face many of the same organizational challenges. Both models involve substantial delegation of responsibility - neither legislatures nor shareholders in large companies directly control the daily activities of an enterprise. In both cases, the hierarchy of authority terminates in managers who typically have a great deal of autonomy and discretion. Rent seeking occurs in private enterprises, just as it does in public enterprises. For instance, Shleifer and Vishny (1989) and Edlin and Stiglitz (1995) have shown that there are strong incentives not only for private rent seeking on the part of management, but also for taking actions that increase the scope for rent seeking. In the Czech Republic the bold experiment with voucher privatization seems to have foundered on precisely these issues. The issue may not be that public organizations cannot provide just as effective incentives, but that typically they do not, and that they impose a variety of additional constraints.

Not only are the differences between public and private enterprises blurry, but there is also a continuum of arrangements in between. Corporatization, for instance, maintains government ownership but shifts toward hard budget constraints and self-financing. (Another alternative is performance-based government organizations, which use output-oriented performance measures.) Some evidence suggests that many of the gains from privatization occur prior to privatization - they arise from the process of corporatization, from putting in place effec- 
tive individual and organizational incentives (Caves and Christensen 1980; Pannier 1996).

The importance of competition rather than ownership has been vividly demonstrated by the very different experiences of China and Russia. China has managed to sustain double-digit growth by extending the scope of competition, without privatizing state-owned enterprises. To be sure, there are a number of problems in the state-owned sector that should be addressed in the next stage of reforms. In contrast, Russia has privatized a large fraction of its economy without doing much so far to promote competition. The consequence of this and other factors has been a major economic collapse.

The magnitude and duration of this collapse is itself somewhat of a puzzle, at least for standard economic theory. The Soviet economy was widely considered rife with inefficiencies, and a substantial fraction of its output was devoted to military expenditures. The elimination of these inefficiencies should have raised GDP ${ }^{16}$ while the reduction in military expenditures should have increased personal consumption still further. Yet neither seems to have occurred.

The magnitude of the success of China's economy over the past two decades also represents a puzzle for standard theory. The economy not only eschewed a strategy of outright privatization, but has also failed to incorporate numerous other elements of the Washington Consensus. Yet China represents the greatest success story of the last two decades. This can be seen in a number of different ways. If China's 30 provinces were separate economies (and many of them have populations exceeding those of most other low-income countries), they would have made up the 20 fastest-growing economies between 1978 and 1995 (World Bank 1997a). Alternatively, almost two-third's of aggregate growth in low-income countries between 1978 and 1995 is accounted for by the increase in China's GDP (by contrast, its GDP in 1978 represented only about one-quarter of the aggregate GDP of low-income countries and its population represented only 40 percent of the total).$^{17}$ One of the important lessons of the contrast between China and Russia is for the political economy of privatization and competition. Privatizing monopolies creates huge rents. It has proved difficult to administer privatization without encouraging corruption and other problems. Entrepreneurs will have the incentive to try to secure privatized enterprises rather than invest in creating their own firms. In contrast, competition policy often undermines rents and creates incentives for wealth creation. Furthermore, the sequencing of privatization and regulation is very important. Privatizing a monopoly can create a powerful entrenched

16 We can think of this either as a movement toward the production possibilities frontier or as an outward shift of the production possibilities curve (a technological "improvement"), where the curve has embedded in it the institutional constraints reflecting how production and distribution are organized.

17 These calculations are based on World Bank data. While measurement problems make it difficult to make such comparisons with any precision, the broad picture we have drawn remains persuasive: real incomes and consumption have fallen in the former Soviet empire, and real incomes and consumption have risen remarkably rapidly in China. 
interest that undermines the possibility of regulation or competition in the future (Stiglitz 1989).

That being said, however, there are critical issues about the sequencing and scope of privatization: even when privatization increases productive efficiency, there may be problems in ensuring that broader public objectives, not well reflected in market prices, are attained, and regulation may be an imperfect substitute. Should prisons, social services, or the making of atomic bombs (or the central ingredient of atomic bombs, highly enriched uranium) be privatized as some in the United States have advocated? Where are the boundaries? One can introduce more private sector activity into public activities, for example, through contracting, and more incentive-based mechanisms like auctions. How effective are these as substitutes for outright privatization? These are issues that all too often the Washington Consensus has suppressed under the mantra of privatization.

Moreover, as we have seen, sequencing matters, not only because many of the benefits of privatization are achieved only in the context of competitive markets, but also because powerful interests groups can be created that suppress competition or that resist regulations to curb the abuses of monopoly power.

Regulation. Even accepting that competition is an essential ingredient of a successful market economy, there are still some sectors of the economy in which competition is not viable - the so-called natural monopolies. The extent and form of competition, however, are constantly changing. New technologies have expanded the scope for competition in many sectors that have historically been highly regulated, such as telecommunications and electric power.

Traditional regulatory structures, however, with their rigid categories of regulation or deregulation, and competition or monopoly, have been increasingly unhelpful guides to policy in these areas. The new technologies do not call for wholesale deregulation because not all parts of these industries are adequately competitive. Instead, they call for appropriate changes in regulatory structure to meet the new challenges. Such changes must recognize the existence of hybrid areas of the economy, some part of which are more suited to competition, while others are more vulnerable to domination by a few. Market power in one part of a regulated industry cannot be allowed to maneuver itself into a stranglehold over other parts, or else economic efficiency may be severely compromised.

COMPETITION POLICY. Although the scope of viable competition has expanded, competition is for a variety of reasons often far less than perfect, especially in developing countries. We have come to understand the variety of ways in which competition is suppressed - from implicit collusion to predatory pricing. We know that control of the distribution system may effectively limit competition even when there are many producers. We have become aware of the potential for vertical restraints in restricting competition. And just as new technologies have opened up new possibilities for competition, so too have they opened up new opportunities for anticcompetitive behavior, as recent cases in the U.S. airline and computer industries have evidenced. 
The development of effective antitrust laws for developing countries remains an understudied area. Surely the sophisticated and complicated legal structures and institutions that characterize antitrust in the United States are unlikely to be appropriate for many developing countries. There may have to be greater reliance on per se rules.

Competition policy also has important implications for thinking about trade policy. Currently, most countries have separate rules governing domestic competition and international competition (Australia and New Zealand are exceptions). With little if any justification, the rules governing competition in international trade (for example, antidumping provisions and countervailing duties) are substantially stricter than domestic antitrust laws (Stiglitz 1997). Under many countries'laws on international trade, much of what is viewed domestically as healthy price competition is classified as dumping. These abuses of fair trade were pioneered in the advanced economies but are now spreading to developing economies - which for the first time in 1996 surpassed industrial countries in the initiation of antidumping actions reported to the General Agreement on Tariffs and Trade/World Trade Organization (GATT/WTO; World Bank 1997b). The best way to curtail these abuses is the full integration of fair trade and fair competition laws, based on the deep understanding of the nature of competition that antitrust authorities and industrial organization economists have amassed over the course of a century.

\section{Government as a Complement to Markets}

So far I have been discussing the ways in which the Washington Consensus was insufficent on the issues of macroeconomic stabilization, financial reform, liberalized trade, and privatization. It contained important elements, but in many ways it did not go far enough in promoting issues like financial sector reform and competition policy. There are vital questions that the Washington Consensus did not even address (or underemphasized). The first set of issues concerns what the government should do; the second, how it can do what it does more effectively.

For much of this century people have looked to government to do more-spend more and intervene more. Government spending as a share of GDP has grown with these demands (figure 6). The Washington Consensus policies I have discussed were based on a rejection of the state's activist role and the promotion of a minimalist, noninterventionist state. The unspoken premise is that governments are presumed to be worse than markets. Therefore the smaller the state, the better (that is, less bad) the state.

As should be clear from my remarks, I do not believe in blanket statements such as "government is worse than markets." I I have argued that government has an

18 The enormous success of steel mills and shipping yards in many of the East Asian countries-the highest productivity in the world-provides an important counterpoint to standard ideological positions. We do not fully understand why these countries were so successful in their state-owned enterprises while so many others were failures. But I have discussed how many have exaggerated the differences between incentives in large private and public organizations. 
important role in responding to market failures, which are a general feature of any economy with imperfect information and incomplete markets. The implication of this view is that the task of making the state more effective is considerably more complex than the task of just shrinking its size.

Typically, the state is involved in too many things and its activities lack focus and concentration. As a result, the state is less effective than it might be. Trying to get government to focus on the fundamentals - economic policies, basic education, health, roads, law and order, environmental protection - is a vital step. But focusing on the fundamentals is not a recipe for minimalist government. The state has an important role to play in appropriate regulation, industrial policy, social protection, and welfare. The choice should not be whether the state should or should not be involved. Rather, it is often a matter of how it gets involved. More important, we should not see the state and markets as substitutes.

I would argue that the government should see itself as a complement to markets, undertaking those actions that make markets fulfill their functions better - as well as correcting market failures. We have already discussed one important instance of a sector that simply does not function well without appropriate government regulations - the financial sector (Stiglitz 1993). Countries with successful economies also have governments that are involved in a range of other activities. In some cases an argument can be made that the government has proven to be an effective catalyst - its actions help solve the problem of an undersupply of (social) innovation. But once it has performed its catalytic role, it needs to withdraw. Thus in the United States the government established a national mortgage system, which has lowered borrowing costs and made mortgages available to millions of Americans leading to one of the highest home ownership rates in the world. But having done this, the time may be at hand for the government to turn this activity over to the private sector.

In this paper I cannot review all, or even the most important, areas in which government can serve as a vital complement to markets. I shall discuss briefly only two: one in which there is little disagreement about the paramount role of government, and one that attracts less attention.

Human CAPITAL. The role of human capital in economic growth has long been appreciated. Studies have found that the returns to an additional year of education in the United States, for instance, are between 5 and 15 percent. ${ }^{19}$ Growth accounting also attributes a substantial portion of growth in developing countries to human capital accumulation. The East Asian economies, for instance, emphasized the role of government in providing universal education, which was a necessary part of their transformation from agrarian to rapidly industrializing economies.

Left to itself, the market will tend to underprovide human capital. It is very difficult to borrow against the prospects of future earnings since human capital itself is

19 For a general survey see Willis (1986). More recent studies include Kane and Rouse (1995) and Ashenfelter and Krueger (1994). 
not collaterizable. These difficulties are especially severe for less wealthy families. The government plays an important role in providing public education, using other methods to make education more affordable and enhancing access to funding.

Transfer of TECHNOLOGy. Studies of the returns to research and development in industrial countries have consistently found individual returns in the range of 20 to 30 percent and social returns of 50 percent or even higher - far exceeding the returns to education (Nadiri 1993). Growth accounting usually attributes the majority of per capita income growth to improvements in total factor productivity-Solow's (1957) pioneering analysis attributed 87.5 percent of the increase in output per personhour between 1909 and 1949 to technical change. ${ }^{20}$ Based on a standard Cobb-Douglas production function, the Republic of Korea's per capita income in 1990 would have been only \$2,041 (in 1985 international dollars) if it had relied solely on capital accumulation. In reality its per capita income was $\$ 6,665$, three times higher. The difference comes from increasing the amount of output per unit of input, which is partly a result of improvements in technology.

The case that, by itself, the market underprovides technology is even more compelling than the case for education. Investments in technology are subject to similar financing problems as education because the investment cannot be used as collateral. Investments in research and development are also considerably more risky and open up much more serious adverse selection problems. More important, technology has enormous externalities. Knowledge is like a public good - you cannot exclude others from enjoying the benefits (nonexcludability) and one person's consumption does not diminish another's ability to consume it (nonrivalrous). As one of the great U.S. presidents, Thomas Jefferson, once said, ideas are like a candle, you can use them to light other candles without diminishing the original flame. As such, the benefits to society of increased investment in technology far outweigh the benefits to individual entrepreneurs. Without government action there will be too little investment in the production and adoption of new technology.

For most countries not at the technological frontier, facilitating the transfer of technology has much higher returns than original research and development. Policies to facilitate the transfer of technology are thus one of the keys to development. One aspect of these policies is investing in human capital, especially in higher education. The argument for funding universities is not just the provision of human capital to particular individuals, but the major externalities that come from enabling the economy to import ideas. Of course many developing countries have high unemployment rates for university graduates and have many more

20 This is not always the case. According to the official growth accounting by the U.S. Bureau of Labor Statistics, total factor productivity has actually fallen since 1978. These numbers are thoroughly implausible, however, and there is considerable controversy about their interpretation. Part of the problem with the recent numbers may lie in the biases in the measurement of inflation. 
university graduates employed in unproductive civil service jobs. These countries have probably overemphasized liberal arts education. In contrast, Korea has narrowed the productivity gap with the world's lead economies through the training of scientists and engineers (figure 7).

Another policy that can promote the transfer of technology is foreign direct investment. Singapore, for example, was able to assimilate rapidly the knowledge that came from its large inflows of foreign direct investment.

Finally, I would like to note briefly that the policies adopted by technological leaders also matter. There can be a tension between the incentives to produce knowledge and the benefits from more effective dissemination. In recent years there has been much concern - including on the part of small firms in industrial countries, the academic community throughout the world, and many people in developing countries - that the balance industrial countries have struck, often under pressure from special interest groups, underemphasizes dissemination. The consequences, they argue, may slow both the overall pace of innovation and adversely affect living standards in both richer and poorer countries. ${ }^{21}$

\section{Making Government More Effective}

Let me return for a moment to our objective of this part of the talk: how do we design policies that increase the productivity of the economy? I have stressed that we should not confuse ends with means; that the elements emphasized by the Washington Consensus may have been reasonable means for addressing the particular set of problems confronting, say, the Latin American economies in the 1980s, but may not be the only, or even the central, elements of policies aimed at addressing problems in other circumstances.

Part of the strategy for a more productive economy that I have just stressed is ascertaining the appropriate role for government: identifying for instance, the ways in which government can be a more effective complement to markets. I now want to turn to another essential element of public policy: how we can make government more effective in accomplishing the tasks it undertakes. World Development Report 1997: The State in a Changing World shows that an effective state is vital for development (World Bank 1997c). Using data from 94 countries over three decades, the report shows that it is not just economic policies and human capital, but the quality of a country's institutions that determine economic outcomes. Institutions, in effect, set the overall environment under which markets operate. A weak institutional environment allows greater arbitrariness on the part of state agencies and public officials.

21 Knowledge is an input - a key input - into the production of knowledge: an increase in the "price" of knowledge (as a result of stricter intellectual property standards) may thereby reduce the production of knowledge. There is also a concern that too many resources go to research directed at trying to convert "common knowledge" into a form that is appropriable. While in principle "novelty" standards are intended to guard against this activity, in practice the line is never perfectly clear, and stricter intellectual property regimes are more likely to commit errors of privatizing public knowledge - and of thereby creating incentives for misdirecting intellectual energies in that direction. 
Given very different starting points, unique histories, cultures, and societal factors, how can states be made more effective? Part of the answer is that the state should match its role to its capability. What the government does, and how it does it, should obviously reflect the capabilities of the government - and those of the private sector. Low-income countries often have weaker markets and weaker government institutions. It is especially important, therefore, that they focus on how they can most effectively complement markets.

But capability is not destiny. States can improve their capabilities by reinvigorating their institutions. This does not mean merely building administrative or technical capacity. More important, it means instituting rules and norms that provide state officials with incentives to act in the collective interest while restraining arbitrary action and corruption. Five interrelated mechanisms can help to enhance state capability:

- Rules and restraints are crucial for a professional and capable bureaucracy. An independent judiciary, institutional checks and balances through the separation of powers, and effective watchdogs can all restrain arbitrary state action and corruption.

- The civil service needs to be more effective, offering competitive wages to attract talented people.

- State capability can also be enhanced through voice and partnerships by bringing the government close to the people and by seeking stakeholder feedback in policymaking and service delivery.

- There are ways in which governments can improve their efficiency and efficacy by using market-like mechanisms in the public sector, for instance, designing and using performance standards, establishing incentive systems based on performance standards, employing auctions for procurement and selling such public assets as spectrum licenses, and using performance standards for regulation in areas like environment and safety.

- The state needs to adopt policies that reduce the scope for rent seeking. Market mechanisms, like auctioning off natural resources or spectrum allocations, are one way to reduce the private sector's incentive to push for the artificial creation of scarcity. In addition, curtailing discretionary activities - such as licensing and trade restrictions - also reduces rent seeking.

\section{Broadened Goals of Development}

The Washington Consensus advocated a set of instruments (including macroeconomic stability, liberalized trade, and privatization) to achieve a relatively focused goal (economic growth). The post-Washington Consensus begins by recognizing that a broader set of instruments is necessary to achieve those goals. I have discussed some of most important instruments, including financial regula- 
tion, competition policy, investments in human capital, and policies to facilitate the transfer of technology.

My second theme here is that the post-Washington Consensus also recognizes that our goals are much broader. We seek increases in living standards, including improved health and education - not just increases in measured GDP. We seek sustainable development, which includes preserving our natural resources and maintaining a healthy environment. We seek equitable development, which ensures that all groups in society enjoy the fruits of development, not just the few at the top. And we seek democratic development, in which citizens participate in a variety of ways in making the decisions that affect their lives.

Knowledge has not kept pace with the proliferation of our goals. We are only beginning to understand the relationship between democratization, inequality, environmental protection, and growth. What we do know holds out the promise of developing complementary strategies that can move us toward all of these objectives. But we must recognize that given our highly multidimensional objectives, not all policies will contribute to all objectives. There will be tradeoffs and hard choices. We need to improve our understanding of these inevitable tradeoffs if we are going to make more informed choices in the future.

I would like to illustrate this by discussing four policy areas, two in which policies can achieve complementary goals and two in which tradeoffs are inevitably involved.

\section{Complement 1: Education}

Promoting human capital is one example of a complementary policy, one that can help promote economic development, equality, participation, and democracy. Again the East Asian experience contains important lessons. I have already discussed the role of education in promoting human capital and growth. In East Asia, universal education also created a more egalitarian society, facilitating the political stability that is a precondition for successful long-term economic development. Furthermore, education - especially education that emphasizes critical, scientific thinking - can help train citizens to participate more effectively and more intelligently in public decisions.

\section{Complement II: Environment}

A second set of ways in which a single instrument can help achieve multiple goals comes from environmental policy. Consider, as an example, the joint implementation of a policy for reducing carbon emissions.

To minimize global climate change, the world needs to devise strategies to reduce the production of greenhouse gasses, especially carbon dioxide, which is produced primarily by combustion. The reduction of carbon emissions is truly a global problem: all carbon emissions enter the atmosphere, producing global consequences that are independent of their geographical origin. 
Joint implementation gives industrial countries (or companies within them) credit for emissions reductions that they might not otherwise have undertaken anywhere in the world. It may be a feasible first step toward designing an efficient system of emission reductions because it requires commitments only from industrial countries and therefore does not entail resolving the huge distributional issues involved in systems of tradable permits or in the undertaking of obligations by developing countries.

The premise of joint implementation is that the marginal cost of carbon reductions may differ markedly in different countries. In particular, developing countries are typically less energy efficient than industrial countries. As a result the marginal cost of carbon reduction in developing countries may be substantially lower than in industrial countries. The World Bank has offered to set up a carbon investment fund that would allow countries and companies that needed to pursue emissions reductions to invest in carbon-reducing projects in developing countries. For developing countries this plan would offer increased investment flows and pro-environment technology transfers. These projects would also be likely to reduce the collateral environmental damage caused by dirty air. And for industrial countries joint implementation allows carbon emissions to be reduced at a lower cost. This is a strategy that is designed to benefit developing countries as it improves the global environment.

\section{Tradeoff I: Investments in Technology}

Not all policies are about complementary goals, such as investing in primary education or jointly implementing emissions reductions. Many policies entail tradeoffs. It is important to face these tradeoffs and to make choices about priorities. Concentrating solely on "win-win" can lead policymakers to ignore important decisions about "win-lose" policies. One important example of a potential tradeoff is investments in technology. Earlier I mentioned how investments in tertiary technical education promote the transfer of technology and thus economic growth. The direct beneficiaries of these investments, however, are almost inevitably better off than average. The result is likely to be rising inequality.

More generally, the transfer of technology may even increase inequality. Although some innovations benefit the worst-off, much technological progress raises the marginal products of those who are already more productive. Even when it does not, the opportunity cost of public investment in technology might be foregone investment in antipoverty programs. By increasing output, however, these investments can benefit the entire society. The potential trickle down, however, is not necessarily rapid or comprehensive.

\section{Tradeoff II: Environment and Participation}

My second example of a tradeoff is between environmental goals and participation. We now recognize that participation is essential. But while participation is 
essential, we should not be confused: participation is not a substitute for expertise. Studies have shown, for instance, that popular views on the ranking of various environmental health risks are uncorrelated with the scientific evidence (EPA 1987; Slovic, Layman, and Flynn 1993). In pursuing environmental policies, do we seek to make people feel better about their environment, or do we seek to reduce real environmental health hazards? There is a delicate balance here, but at the very least, more dissemination of knowledge can result in more effective participation in formulating more effective policies.

\section{Concluding Remarks}

I would now like to make some concluding remarks. The goal of the Washington Consensus was to provide a formula for creating a vibrant private sector and stimulating economic growth. In retrospect the policy recommendations were highly risk averse. They were based on the desire to avoid the worst disasters. Although the Washington Consensus provided part of the foundation for well-functioning markets, it was incomplete and sometimes even misleading. The World Bank's (1993) East Asian miracle study was a significant turning point in the discussion . It showed that the stunning success of the East Asian economies depended on much more than just macroeconomic stability or privatization. I have explicitly discussed the lessons of the East Asian miracle elsewhere (Stiglitz 1996), but the general ideas pervade all of my remarks here. Without a robust financial system - which the government plays a huge role in creating and maintaining - it is difficult to mobilize savings or to allocate capital efficiently. Unless the economy is competitive, the benefits of free trade and privatization will be dissipated in rent seeking, not directed toward wealth creation. And if public investments in human capital and technology transfers is insufficient, the market will not fill in the gap.

Many of these ideas and others not mentioned here are the basis of what I see as an emerging consensus, a post-Washington Consensus consensus. One principle of these emerging ideas is that whatever the new consensus is, it cannot be based on Washington. For policies to be sustainable, they must be owned by the developing countries that will implement them. It is relatively easy to monitor and set conditions for inflation rates and current account balances. Doing the same for financial sector regulation or competition policy is neither feasible nor desirable. The second principle of the emerging consensus is a greater degree of humility, the frank acknowledgement that we do not have all the answers. Continued research and discussion not just between the World Bank and the International Monetary Fund, but throughout the world is essential if we are to better understand how to achieve our many goals. 
Figure 1. Public Sector Deficits: Latin America versus East Asia

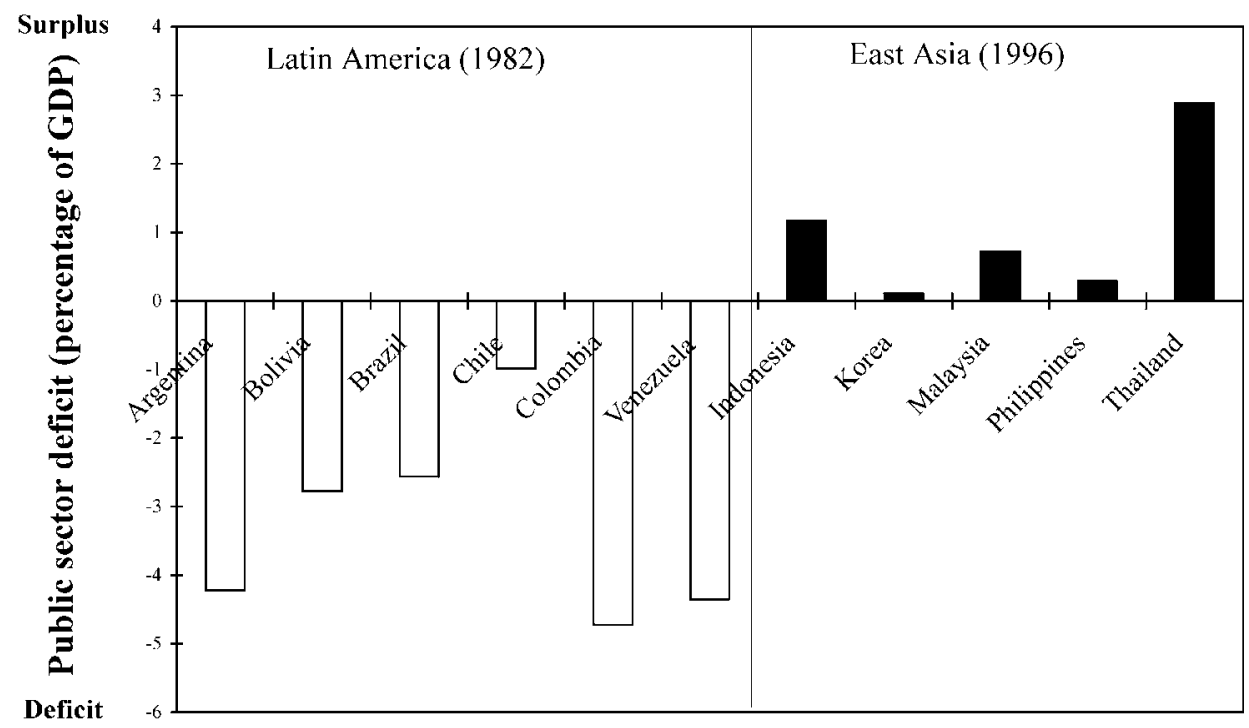

Note: Calculations based on data from IMF International Financial Statistics Database. Figures for Thailand are from 1995.

Figure 2. Inflation: Latin America versus East Asia

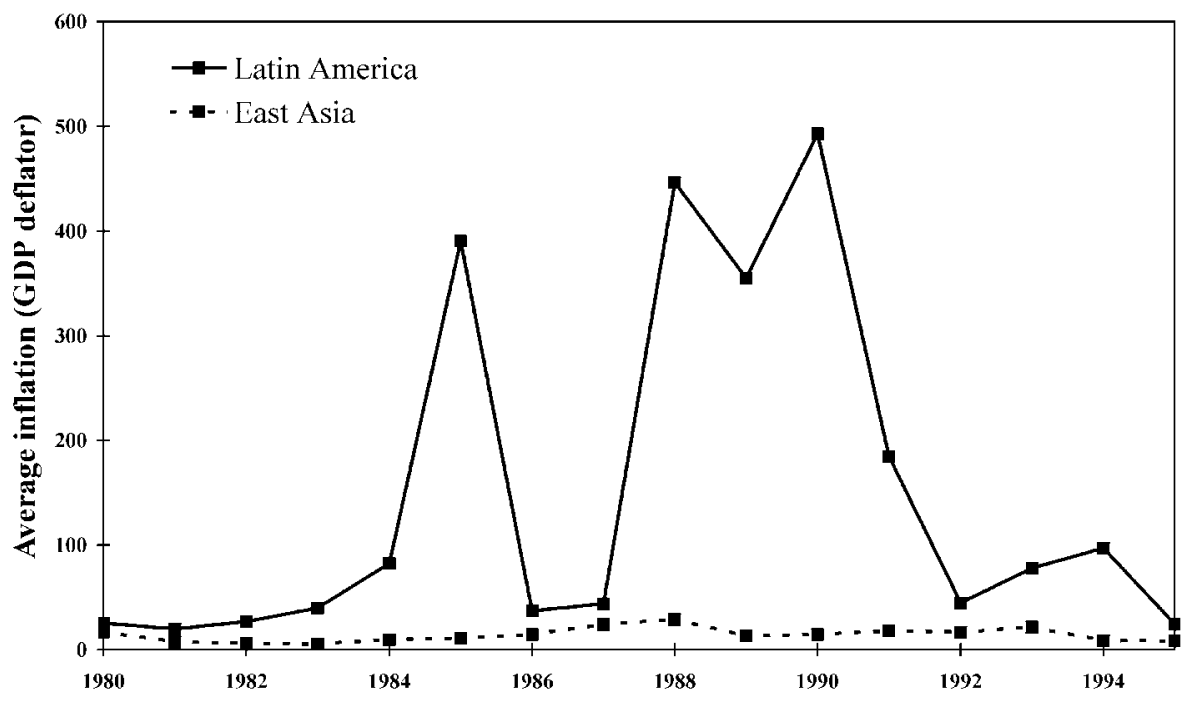

Note: Unweighted regional averages based on World Development Indicators 1997 data. 
Figure 3. Inflation Rates in Developing Countries 1985, 1995

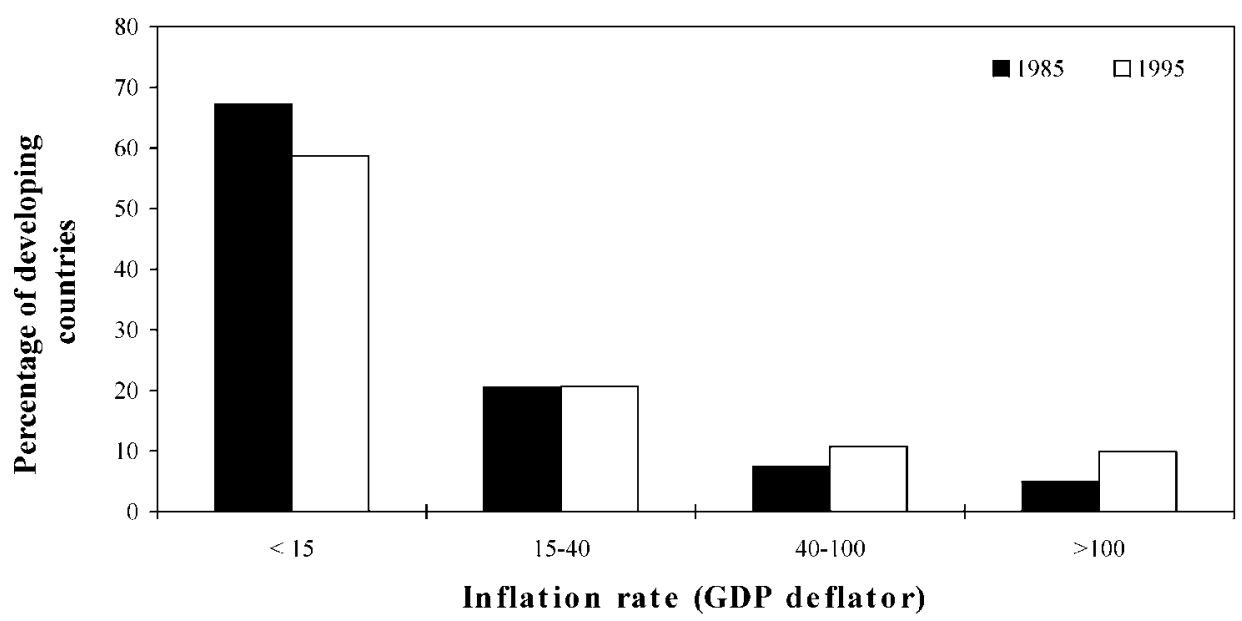

Source: World Development Indicators 1997.

Note: 121 of 158 low- and middle-income countries.

Figure 4. Volatility of GDP Growth, 1970-1995

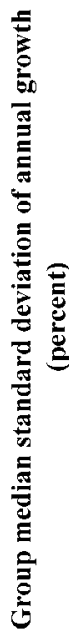

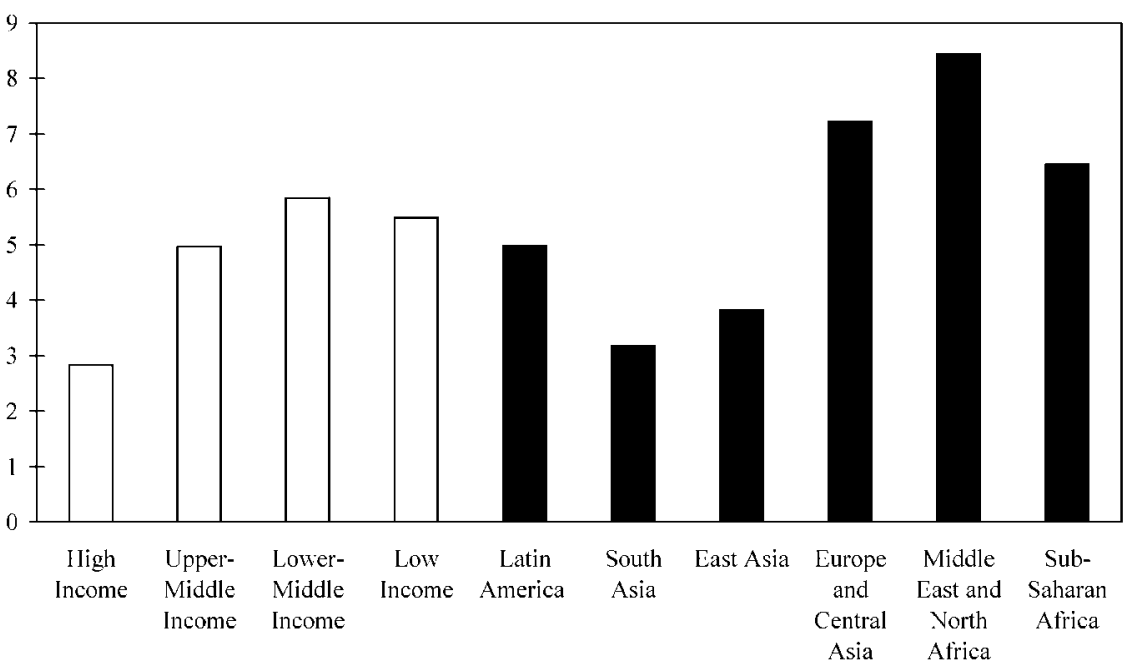

Source: Calculations based on real annual growth from World Development Indicators 1997. 
Table 1. Fiscal Costs of Banking Crises (Percentage of GDP)

\begin{tabular}{lc}
\hline Country (Date) & Cost \\
\hline Argentina (1980-1982) & $55.3 \%$ \\
Chile (1981-1983) & $41.2 \%$ \\
Uruguay (1981-1984) & $31.2 \%$ \\
Israel (1977-1983) & $30.0 \%$ \\
Côte d'Ivoire (1988-1991) & $25.0 \%$ \\
Senegal (1988-1991) & $17.0 \%$ \\
Spain (1977-1985) & $16.8 \%$ \\
Bulgaria (1990s) & $14.0 \%$ \\
Mexico (1995) & $13.5 \%$ \\
Hungary (1991-1995) & $10.0 \%$ \\
Finland (1991-1993) & $8.0 \%$ \\
Sweden (1991) & $6.4 \%$ \\
Sri Lanka (1989-1993) & $5.0 \%$ \\
Malaysia (1985-1988) & $4.7 \%$ \\
Norway (1987-1989) & $4.0 \%$ \\
United States (1984-1991) & $3.2 \%$ \\
\hline
\end{tabular}

Source: Caprio and Klingebiel (1996).

Figure 5. GDP Growth before and after Banking Crises, 1975-1994

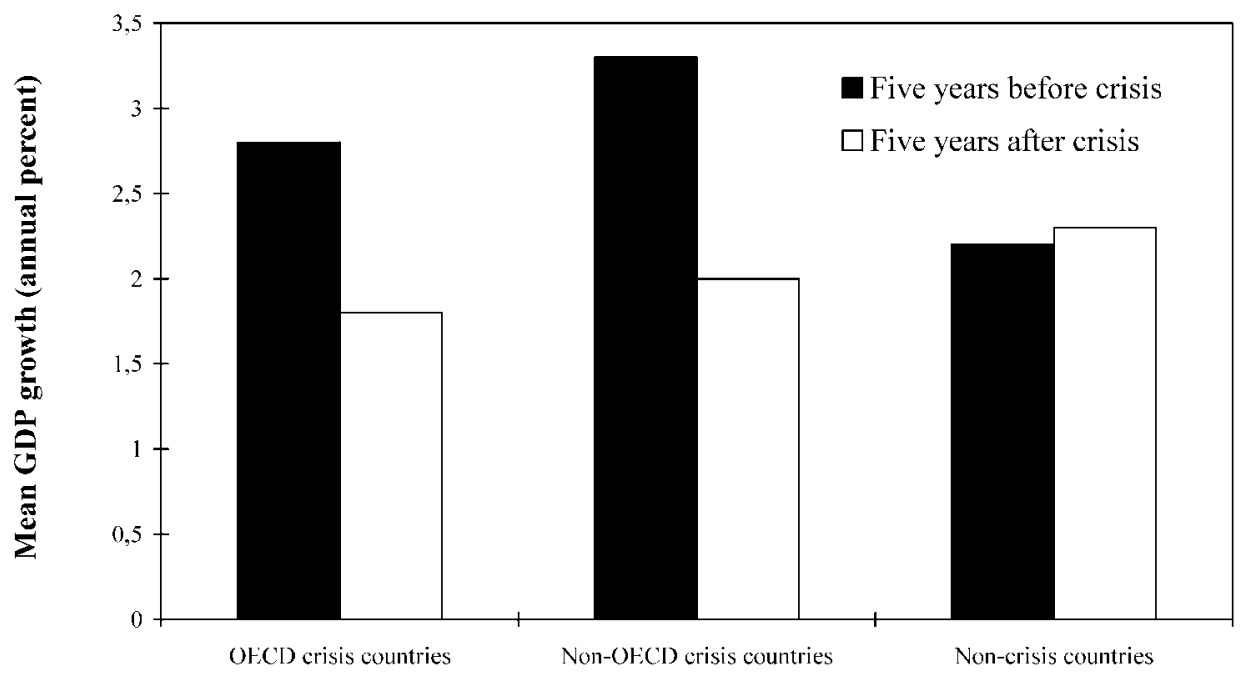

Source: Caprio (1997). 
Figure 6. Government Spending in Selected Countries

(as a percentage of GDP)

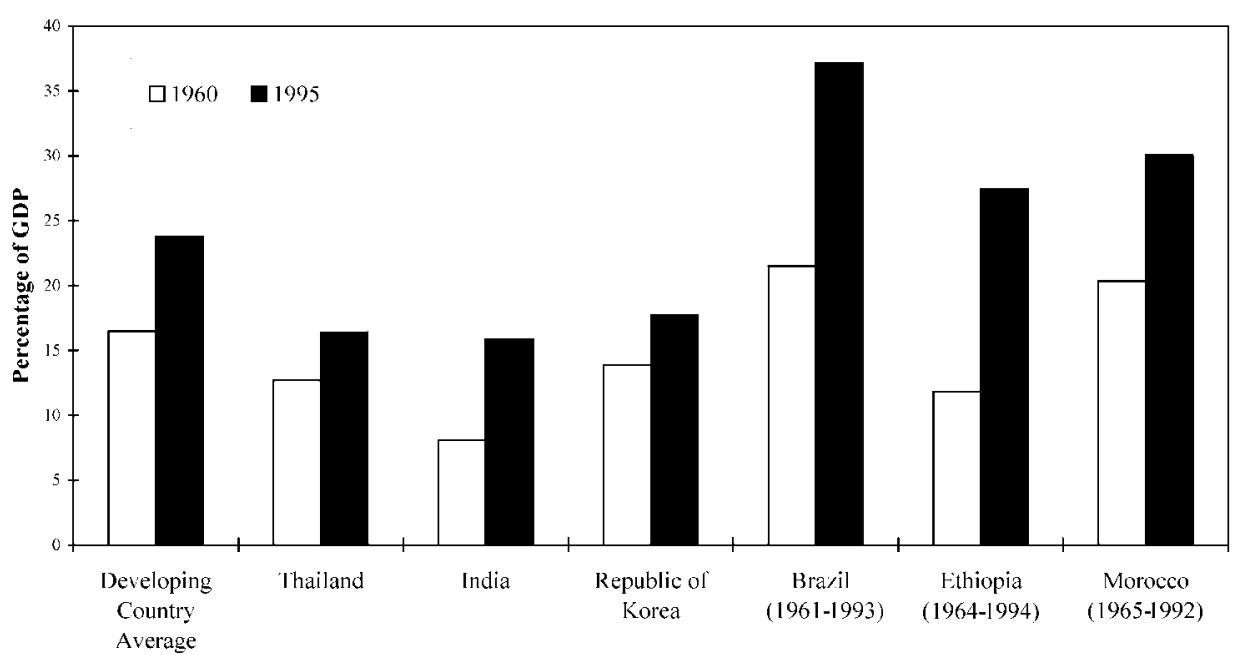

Note: Data from IMF Government Financial Statistics.

Figure 7. Tertiary Level Students in Technical Fields (percentage of population)

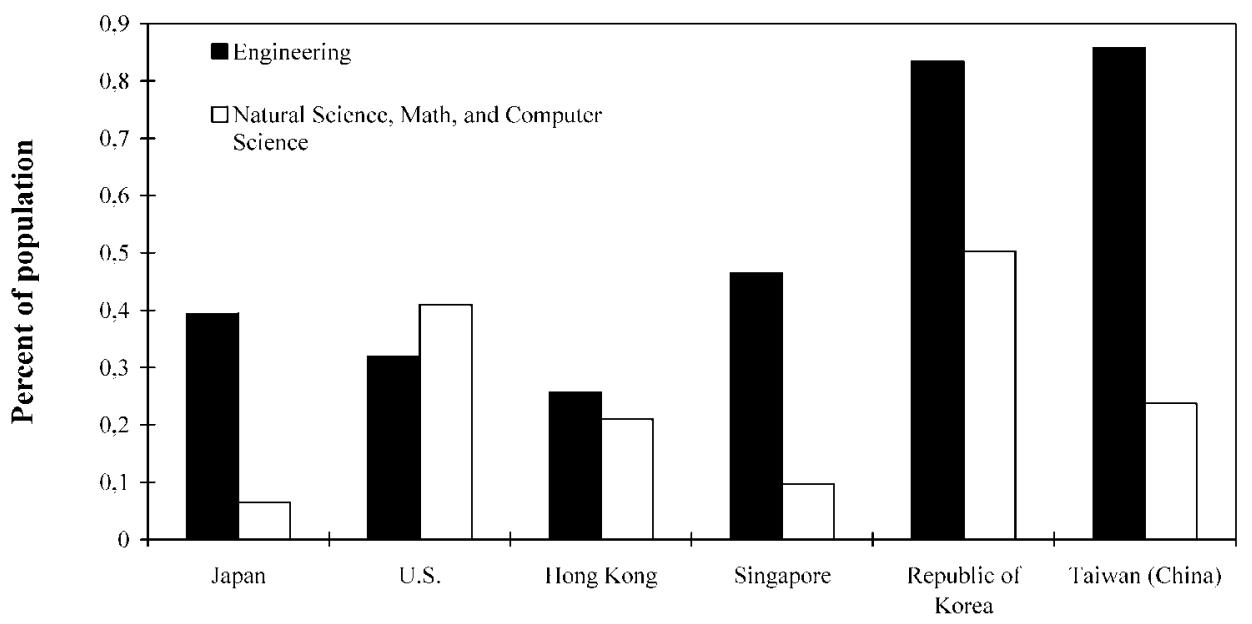

Source: UNESCO, Statistical Yearbook 1995, Government of Taiwan, Taiwan Statistical Yearbook 1994, Ministry of Education (Singapore). 


\section{References}

Akerlof, G., W. Dickens, and G. Perry. 1996. “The Macroeconomics of Low Inflation.” Brookings Papers on Economic.Activity, 1. Washington, D.C.: The Bookings Institution.

Ashenfelter, Orley, and Alan Krueger. 1994. "Estimates of Economic Returns to Schooling from a New Sample of Twins." American Economic Review (December).

Barro. Robert.1974. “Are Government Bonds Net Wealth?”Journal of Political Economy 81(6): 1095-117. 1997. Determinants of Economic Growth. Cambridge, Mass.: MIT Press.

Caprio. Gerard. 1997. "Safe and Sound Banking in Developing Countries: We're Not in Kansas Any More." Research in Financial Services: Private and Public Policy 9: 79-97.

Caprio, Gerard, and Daniela Klingebiel (1996). "Bank Insolvencies: Cross Country Experience.” Policy Research Working Paper 1620. World Bank, Department Economics Development Research Group, Washington, D.C.

1997. "Bank Insolvency: Bad Luck, Bad Policy, or Bad Banking?” In Michael Bruno and Boris Pleskovic, eds., Annual World Bank Conference on Development Economics. Washington, D.C.: World Bank.

Caves, Douglas, and Laurits Christensen (1980). "The Relative Efficiency of Public and Private Firms in a Competitive Environment: The Case of Canadian Railroads,"Journal of Political Economy. 88:5.pp. 958-976.

Council of Economic Advisers (1997). Economic Report of the President 1997. Washington, D.C.: Government Printing Office.

Demirguc-Kunt. Asli. and Enrica Detraoiache (1997). 'The determinants of banking crises: evidence from industrial and developing countries.' World Bank Policy Research Working Paper No. 1828. September.

Easterly William. Carlos Rodriguez. and Klaus Schmidt-Hebbel. eds. (1994). Public Sector Deficits and Macroeconomic Performance. Washington. D.C.: World Bank.

Edlin. Aaron and Joseph E. Stiglitz (1995). Discouraging Rivals: Managerial Rent Seeking and Economic Inefficiencies. American Economic Review 85(5). pp. 1,01-1.

Environmental Protection Agency (1987). Unfinished Business: A Comparative assessment of Environmental Problems. Washington. D.C.: EPA

Feldstein. M. (1996), The Costs and Benefits of Going from Low Inflation to Price Stability,-' NBER Working Paper No 5469. Cambridge, Mass. MA.

Fischer. S. (1993), "The Role of Macroeconomic Factors in Growth," Journal of Monetary Economics, 32, pp. 485-512.

Greenwald. Bruce and Joseph E. Stiglitz (1986). "Externalities in Markets with Imperfect Information and Incomplete Markets," Quarterly Journal of Economics. May, pp. 9r9-264.

Greenwald. Bruce and Joseph E. Stiglitz (1988). "Examining Alliterative Macroeconomic Theories." Brookings Papers on Economic. Activity No. 1. pp. 207-970.

Greenwald. Bruce and Jospeh E. Stiglitz (1993a). Financial Market Imperfections and Business Cycles. Quarterly Journal of Economics. 108(1), February, pp. 77-114.

Greenwald. Bruce and Joseph E. Stiglitz (1993b). "New and Old Keynesians," Journal of Economic Perspectives 7(1) Winter, pp. 9344.

Kane. Thomas and Cecilia Rouse (1995). "Labor Market Returns to Two- and Four-Year College: is a Credit a Credit and Do, Degrees Matter?", American Economic Review Vol. 85. No. 3. DD. 600-14.

Nadiri. Ishaq (1993). "Innovations and Technological Spillovers," .VBER Corking Paper Series, Working Paper No. 4423, August.

Pannier. Dominique ed. (1996). Corporate Governance of Public Enterprises in Transitional Economies. World Bank Technical Paper No. 393. Washington. D.C.: World Bank.

Pritchett. Lant (1997). Patterns of Economic Growth: Hills. Plateaus. Mountains. Cliffs. and Plains. Unpublished mimeo.

Rey. Patrick and Joseph E. Stiglitz (1993). Short-term Contracts as a Monitoring Device. NBER Working Paper No. 4514, Cambridge. Mass.

Sappington. David and Joseph E. Stiglitz (1987). Privatization. Information and Incentives. Journal of Policy Analyses and Management. 6(4).pp. 567-589. 
Shleifer, Andrei, and Robert Vishny (1989). Management Entrenchment: The Case of Manager-Specific Investments. Journal of Financial Economics 25(1):13-39.

Slovic. Paul. Mark Layman. and James Flynn (1993). Perceived Risk. Trust. and Nuclear Waste: Lessons from Yucca Mountain. in R. Dunlap. M. Kraft. and E. Rosa (eds.), Public Reactions to Nuclear Waste. Durham. North Carolina: Duke University Press.

Solow. Robert (19O7). Technical Change and the Aggregate Production Function. Review of Economics and Statistics (August).

Stiglitz, Joseph E. (1989). The Economic Role of the State: Efficiency and Effectiveness, in A. Heertje (ed.) The Economic Role of the Slate. Basil Blackwell and Bank Insinger de Beaufort NV, pp. 9-85.

Stiglitz. Joseph E. (1993). The Role of the State in Financial Markets. Proceeding of the World Bank conference on Development Economics 1993 Washington. D.C.: World Bank.

Stiglitz. Joseph E. (1994). Endogenous Growth and Cycles. in Y. Shionoya and M. Perlman (eds.) Innovation in Technology, Industries. and Institutions University of Michigan Press. pp. I 96.

Stiglitz,Joseph E. (1996). Some Lessons of the East Asian Miracle. World Bank Research Observer.11(2). August. pp. 151-77.

Stiglitz Joseph E. (1997). Central Banking in a Democratic Society, The Tinbergen Lecture, forthcoming.

Williamson,. John (1990). What Washington Means by Policy Reform, in John Williamson (ed.) Latin American Adjustment: How Much Has Happened? Washington, D.C.: Institute for International Economics.

Willis. Robert (1986). Wage Determinants: A Survey and Reinterpretation of Human Capital Earnings Functions, in Orley Ashenfelter and Richard Layard (eds.), Handbook of Labor Economics Volume 1. Amsterdam: Elsevier Science Publishers and North Holland.

World Bank (1993). The East Asian Miracle. New York: Oxford University Press.

World Bank (1997a). China 2020 Washington D.C.: World Bank.

World Bank (1997b). (loyal Economic Prospects and the Developing Countries. Washington. D.C.: World Bank.

World Bank (1997c). World Development Report 1997: The State in a Changing World Oxford: Oxford University Press. 